\title{
Cikkismertetés: Személyiségünk és a korlátozó szabályozásokhoz való alkalmazkodás a Covid-19 járvány alatt
}

\author{
Article review: Our personality and adaptation to restrictions during \\ the Covid-19 pandemic
}

$\begin{array}{ll}\text { Ismertető: } & \text { Kiss Edina } \square \\ & \text { Szabolcs-Szatmár-Bereg Megyei Kórházak és Egyetemi Oktatókórház, } \\ & \text { Sántha Kálmán Szakkórház, Nagykálló }\end{array}$

Ismertetett cikk: Cooper B, Pauletti RE, DiDonato CA. You, Me, and No One Else: Degree of Social Distancing and Personality Predict Psychological Wellness and Relationship Quality During the COVID-19 Pandemic. PsyArXiv Preprints. 2020. October 6. doi: 10.31234/osf.io/w6dr *

Beküldve: $\quad$ 2020.10.17.

doi: $\quad$ 10.24365/ef.v61i4.644

Kulcsszavak: Covid-19; személyiségjellemzők; társas kapcsolatok minősége;

mentális egészség, Big Five

Keywords: Covid-19; personality; relationship quality; mental health;

Big Five

\begin{abstract}
A SARS-CoV-2 vírus okozta betegség, a COVID-19 világszintű terjedése korábban nem ismert mértékben borította fel mindennapi életünk ritmusát és követelte újabb alkalmazkodási készségek gyors kialakítását. A világjárvány egyedülálló lehetőséget biztosított annak feltárására, hogy vannak-e összefüggések az egyes személyiségjellemzők és a társadalmi távolságtartás foka, a karanténszabályok betartásának mértéke, a mentális egészség, illetve az interperszonális kapcsolatok minőségi változása között. Jelen tanulmányt a fent meghatározott célok kitűzésével az Amerikai Egyesült Államokban végezték, 519 fő bevonásával.
\end{abstract}

Kezdetben a terjedési mód és a kórlefolyás hiányos ismeretei gyakran vezettek bizonytalan és zavaros kormányzati szabályozásokhoz a karantén és a társadalmi távolságtartás területén. Ezek különféle reakciókat váltottak ki az egyénekből, eltérő módon küzdöttek meg a pandémia okozta kihívásokkal. Ezek a reakciók megfeleltethetőek az Eysenck által leírt Big Five vonáselméletnek. Az elnevezés arra utal, hogy a személyiség öt nagy dimenzió mentén leírható, ezek az extraverzió, a barátságosság, a lelkiismeretesség, az érzelmi stabilitás-labilitás és a nyitottság.

A felmérésből kiderült, hogy a Covid-19-járvány kedvezőtlen hatást gyakorolt a mentális jóllétre, míg pozitív következményei voltak az egy háztartásban élők kapcsolatainak minőségére. Azon személyek, akiket magasabb fokú kedvesség, nyitottság, lelkiismeretesség és neuroticizmus (érzelmi stabilitás - labilitás dimenzió) jellemez, nagyobb való-

*Kézirat, folyóirat általi elfogadás előtti változat 
színűséggel vesznek részt a megfelelő karanténintézkedések betartásában. Ezzel szemben az extrovertált személyiséggel jellemezhető egyének nehezebben mondanak le a társas interakciókról, emocionálisan megterhelőbbnek érzik a társadalmi távolságtartás követését és a szeparáció okozta magányt intenzívebben élik meg. A felmérés során megfigyelhetővé vált, hogy az online kapcsolattartás a családdal vagy a barátokkal, hozzájárulhat a szeparáció csökkentéséhez. Még ha az egyének nem is tudnak személyesen kapcsolatba lépni másokkal, úgy tûnik az online kapcsolattartás különböző formái átmenetileg megfelelő helyettesítői lehetnek, valamint a mentális jóllét javulásához is hozzájárulnak.

Összességében a jelenlegi tanulmány betekintést nyújt az egyéni különbségek okozta magatartásminták elemezésére a karantén és a társas távolságtartás vonatkozásában.

\section{TANULSÁGOK A HAZAI SZAKEMBEREK SZÁMÁRA}

A holisztikus szemlélet alapján a megfelelő szomatikus állapot eléréséhez és tartós fenntartásához, illetve az immunrendszer megfelelő múködéséhez a mentális jóllét állapota is kardinális fontosságú. Fontos látnunk az elhúzódó járványhelyzet globális: testi-lelki hatásait, illetve értenünk a „pandémiás fáradtság” mögött meghúzódó pszichológiai jelenségek okait vagy az opponáló egyének személyiségjellemzőik által meghatározott reakciókat. Ezek együttesen hozzájárulhatnak a járvány elleni védekezés sikerességéhez. 